Please do not remove this page

RMIT

UNIVERSITY

\title{
Students as global citizens: strategies for mobilizing studies abroad
}

Sison, Marianne; Brennan, Linda-Marie

https://researchrepository.rmit.edu.au/esploro/outputs/9921859147001341/filesAndLinks?institution=61RMIT_INST\&index=null

Sison, M., \& Brennan, L.-M. (2012). Students as global citizens: strategies for mobilizing studies abroad. Journal of Marketing Higher Education, 22(2), 167-181. https://doi.org/10.1080/08841241.2012.736884

Document Version: Accepted Manuscript

Published Version: https://doi.org/10.1080/08841241.2012.736884

Repository homepage: https://researchrepository.rmit.edu.au

(C) 2012 Copyright Taylor and Francis Group, LLC.

Downloaded On 2023/04/26 19:45:42 +1000

Please do not remove this page 
Thank you for downloading this document from the RMIT Research Repository.

The RMIT Research Repository is an open access database showcasing the research outputs of RMIT University researchers.

RMIT Research Repository: http://researchbank.rmit.edu.au/

\section{Citation:}

Sison, M and Brennan, L 2012, 'Students as global citizens: Strategies for mobilizing studies abroad', Journal of Marketing Higher Education, vol. 22, no. 2, pp. 167-181.

See this record in the RMIT Research Repository at:

https://researchbank.rmit.edu.au/view/rmit:18161

Version: Accepted Manuscript

Copyright Statement: (c) 2012 Copyright Taylor and Francis Group, LLC.

Link to Published Version:

http://dx.doi.org/10.1080/08841241.2012.736884 
Students as global citizens: strategies for mobilising studies abroad

Marianne D. Sison and Linda Brennan

School of Media and Communication, RMIT University, Melbourne, Australia

Correspondence details:

Marianne D. Sison, $\mathrm{PhD}$

School of Media and Communication

RMIT University

GPO Box 2476

Melbourne, Victoria 3000

Australia

Email: Marianne.sison@rmit.edu.au

Phone: +61399253127

Fax: +61 396391685

Professor Linda M Brennan

Email: linda.brennan@rmit.edu.au

Phone: + 61399252842 


\section{Students as global citizens: strategies for mobilising studies abroad}

Universities globally are increasingly seeking to improve the international mobility of their students. There are several latent benefits that accrue to a university whose students and staff actively participate in international exchange programs. Essentially this can lead to an increase in the university's international reputation, opportunities for benchmarking against best practices, capacity to develop international relationships, diversity of student population with all the benefits that accrue from diversity and access to potential recruitment markets. In this paper we review extant literature to elicit the range of practical factors that play a role in the decision of students to study abroad. We also discuss results from a recent student survey that revealed students' preferences for international work placements.

Keywords: international education, study abroad, international internships

\section{Introduction}

The vision and mission statements of Australian universities abound with references to 'internationalisation', 'student mobility' and 'global citizenship'. A quick review of the websites of these universities has revealed that majority of them are increasingly seeking to improve the international mobility of their students as a solution to creating global citizens. However, in Australia this push is not succeeding. Currently there is a level of outward-bound student mobility estimated at ranging from somewhere between one and three percent (http://stats.oecd.org). There have been some improvements in recent years with an Australian Government website now devoted to enabling student mobility (www.studyoverseas.gov.au). However, international student mobility remains an issue for a country which aims to be at the forefront of global education.

For the purposes of this paper, we define student mobility in this context as a limited period of study in an international environment - 6 to 12 months (Kehm, 2005). In this context a 'host country' is where the student chooses to study. The 'home 
country' is the country where the student is undertaking their university study; this may or may not be their country of origin or permanent residence.

A recent report from the Australian ALTC indicated that a vision for Australian Universities was to become increasingly international, as well as increasing the value of the contribution of the outward bound experience to Australia and to Australian Universities in particular (Gothard \& Butcher, 2010).

Student mobility is a critical factor in the achievement of this vision, but concerns are raised as to the costs and benefits of pursuing this agenda. In the main, the major beneficiary of an international educational experience is the home country (Kelo, Teichler, \& Wachter, 2006). Some of the benefits of improved student mobility have been described as:

- $\quad$ Enabling students to see first hand the conditions that prevail in other countries and thereby expanding their mental horizons (De Ville, Martou, \& Vandenberghe, 1996; Goodman, Jones, \& Macias, 2007; Kehm, 2005; Marcotte, Desroches, \& Poupart, 2007). Students then returned with more insight and with greater intercultural competencies than they might otherwise have.

- Improvement in the reputation of the host country and the host country's higher education system (Czinkota, 2005; Kehm, 2005; Marginson \& van der Wende, 2007) by way of advocacy from the returning student and by way of the students' improved performance in their home country's class rooms. However, this is a bi-lateral effect with students representing their home country's educational capabilities when expatriate; and their host country's capabilities upon their return. 
- In the longer term, student mobility has led to improvements in international trade opportunities, networks and relationships for the host and home countries (Goodman, et al., 2007; Larsen, Martin, \& Morris, 2002; Larsen, Momii, \& Vincent-Lancrin, 2004). Students develop lasting networks and friendships in their host countries. They also develop a tolerance and understanding of the cultural mores of their host country. These combine to produce 'global citizens' capable of taking their place in a variety of cultural contexts, not just those with which they are experienced.

- Student mobility also leads to demonstrable improvement in international work opportunities for the student upon graduation (Kehm, 2005; Mei Li \& Bray, 2007; Marcotte, et al., 2007; Ulrich Teichler \& Janson, 2007). Students with greater levels of intercultural competence, accumulated within their international experiences, find themselves with more flexible, and more lucrative, opportunities for work both at home and abroad.

- Another outcome of student mobility is the development of cross-cultural knowledge that benefits the home country upon the students' return (De Ville, et al., 1996; Naidoo, 2006). The home country benefits from greater opportunities for trade with other countries, greater capacity to facilitate international relationships and greater levels of tolerance and understanding of different business and trade cultures.

- Student mobility in specialised areas, can lead to the acquisition of specialist knowledge which is not available in the home country (Baruch, Budhwar, \& Khatri, 2007; Bourke, 2000; Tremblay, 2005). This is particularly important in regions where intellectual and social capital is in the developmental stages, such as South East Asia. 
- $\quad$ The advocacy and examples set by mobile (outward bound) students leads to the ability to attract future potential workers to the host country (Kehm, 2005; Tremblay, 2005). For countries with skills shortages such as Australia, this is an important benefit (Coates \& Edwards, 2011).

However, it must be noted, that while these benefits accrue to the home country, only one of them accrues to the student. That benefit is a greater likelihood of international employment and potentially a more lucrative salary (De Ville, et al., 1996; Throsby, 1998). In most countries, students are required to pay for their international experience; either by way of extra fees, travel costs, accommodation, living expenses (which are sometimes quite expensive depending on the home country), and so on. As a consequence, it is not surprising that international mobility is lower than it could be, given that so few outcomes directly benefit the individual student.

Another problem in terms of assessing the benefits of student mobility is that the outcome, to a high degree, is in terms of non-measurable value and hence it is it difficult for a university to fully monitor and estimate the costs of participation in students' mobility (Throsby, 1998). Indeed, it can appear to be that the costs to a university of encouraging student mobility are greater than the benefits, if one is using a purely economically rational argument. The model of 'payment' for study abroad can mean that the home country not only loses money from fees, but subsidises the student (Hemsley-Brown \& Goonawardana, 2007; Strehl, Reisinger, \& Kalatschan, 2007). Thus the intangible, long-term benefit to the host country is attained at the cost of the university who sends their student abroad: a conundrum of the highest order. Encourage students to be mobile and lose a revenue source as a result. 
We set out to explore the barriers and benefits of student mobility and established that they can be summarised under five headings: Academic, Economic, Social, Political and Governmental, and Cultural Issues.

\section{Academic issues}

There are differences in quality assurance systems, processes and outcomes between universities in home and host countries. There is no global credit transfer system although some moves have been made recently to harmonise the systems in Europe (Van Den Broek, Muller, Dekker, Bootsma, \& Cate, 2010) and more recently extended to Latin America (Scott, 2011). Regardless of international differences, students are unable to assess the value of the educational experience in advance of the experience (Mourad, Ennew, \& Kortam, 2011). As a consequence, they must rely on 'the system' to make this assessment of commensurate quality for them. If such as system does not exist, they may 'resort' to rankings of the broader type such as the QS or Jiao Tong.

There is a global ranking system in place that supports the older, more established universities (usually English speaking), at the 'expense' of more eclectic international experiences (Coleman, 2006; Goodman, et al., 2007; Ziguras \& McBurnie, 2011). There is limited demand for study abroad placement in South East Asia for example. In addition, the home country institution has to accept the equivalency of the qualification. Hence, if students do not want to 'waste' their time studying subjects that they will not get credit for at home, they will choose those locations where there is the most similarity to their existing programs, with obvious implications for the diversity of the experience.

The equivalency problem extends to systems of education across the world differing according to their social and cultural roots. Entry requirements will differ. 
Students in the home country may have 12 years of study prior to entry (Australia) but the host country may have 11 (Johnstone, 2010) or 13 (Denmark) @. There may also be a 'liberal arts' component (USA) or not, as is the case in Australia. This ensures that 'mapping' the curriculum outcome is problematic. The lack of a global credit transfer system has been discussed variously (Chase, 2010; Doyle et al., 2010; King, Findlay, \& Ahrens, 2010). However, the complexities of harmonisation remain unaddressed, even when there is a political will to do so (Gleeson, 2011; King, et al., 2010; U. Teichler, 2010). Thus, students who wish to be mobile continue to face large problems with determining the commensurable and equivalent subjects and programs to study, often with little assistance from their faculty (Daly, 2011).

\section{Economic issues}

A major barrier to students travelling is the extra costs incurred as a result of the experience. In Australia, where most students are still living at home (Clifford, 2011; Findlay, King, Smith, Geddes, \& Skeldon, 2011), there will be a significant increase in costs associated with mobility, if only because they will have to find the wherewithal to fund the trip. Furthermore, there is the opportunity cost of working in the home country. Many students are working in excess of 20 hours a week (Biddle, 2006; Metcalf, 2003) (Biddle, 2006; Metcalf, 2003); they have to give up this paid work in order to study abroad. Thus, not only do they have to pay extra living costs, and possibly extra tuition fees, they also have to give up their salaries while they are gone. They are unlikely to get equivalent work in their host country due to language difficulties (Barron, Baum, \& Conway, 2007). Combine this with the actual costs of airfares and the situation potentially becomes economically unviable. A return airfare from Australia to Europe (say Frankfurt) can cost more than $\$ 5,000$ (www.webjet.com). Therefore, a semester 
abroad can cost, in real terms, more than $\$ 20,000$. For which the return-on-investment comes at some intangible distance in the future and may not directly benefit the student.

\section{Social issues}

An important benefit of student mobility is the establishment and development of social networks. While these become particularly valuable for those studying business, there are distinct benefits for other disciplines as well (Kemp, 2011). However, in a rapidly globalising internet-enabled world, sometimes there is no need to leave home to be linked with international connections (Waters, 2006).

The research also demonstrates that international student mobility is most often associated with higher socio-economic status (Altbach, Reisberg, \& Rumbley, 2010; M. Li \& Zhang, 2011; Mutlu, Alacahan, \& Erdil, 2010). It is not clear if this is a function of economic status (i.e. they can afford to travel), or if this is related to the broader horizons that are presented to such students as a result of their 'class.' However, if more than $90 \%$ of students do NOT travel abroad to study (OECD, 2010) and of those, only the 'rich' travel, it makes it difficult for the home country to position study abroad as a normal and usual activity for all students.

Language remains a barrier for students considering study abroad, particularly in Australia where the population, in the main, does not study languages other than English post elementary schooling levels (Baldauf Jr \& White, 2011). The outcome of this can be seen in that most of our mobile students travel abroad to English speaking countries: UK, USA and Canada (Ziguras \& McBurnie, 2011).

\section{Political and governance issues}

In addition to the lack of commensurate systems described above, there are the 'political' motivations for student mobility that sometimes differ between host and 
home country. These inequities can limit the efforts that are put in to student mobility programs from a governance and administration infrastructure perspective. The effort is linked to the perceived advantage of the experience (for the student or home country). The choice is often between instrumental trade advantages (i.e., business students often choose major trading partners of the home country) or holiday (recreational) destinations (where the choice is often Italy) (OECD, 2009). Destinations that are seen to have recreational value versus instrumental value are likely to have less support; leaving the student to make their own arrangements should they want to study somewhere that is not mainstream.

In addition, there are some functional and structural fundamentals such as the term dates and the academic year sequence. The long summer break in Australia is from October to March. Throughout the world, the academic year starts at different times and the terms rarely line up. Thus, Australian students wishing to study abroad may have to, in effect, take an entire year out of their study program in order to line up the respective terms for a single semester of study. In considering these barriers and benefits, this study aimed to develop an international student mobility program for an interdisciplinary school of media and communication, with a commitment to internationalisation from a student-centred perspective.

\section{Approach to the study}

An email was sent to currently enrolled students from an approved student email list of a media and communication school at an Australian university, outlining the aims and purpose of this research and inviting them to participate in the survey. Participants needed to be over the age of 18 and currently enrolled in either an undergraduate or postgraduate program. Participants were asked to respond to a web-based survey by following a hyperlink embedded in the email. A total of 352 students responded to the 
survey, however only 350 surveys were useable. They were asked to rank a set of activities in order of which interests them the most: study tour, study exchange and overseas internship/work placement. After ranking these activities, they answered a series of questions about each of the three activities. The survey took about 15 minutes to complete and participation was anonymous. The results of the survey were then downloaded and analysed using PASW 18. While the results of the preferences will be mentioned, this paper however will focus only on the overseas work placement which the students listed as their preferred student mobility activity.

Table 1: Profile of participants

\begin{tabular}{|c|c|c|c|c|c|c|}
\hline & & \multicolumn{2}{|c|}{ Mode of study } & \multicolumn{2}{|c|}{ Gender } & \multirow[b]{2}{*}{ Total } \\
\hline & & Full time & Part time & Male & Female & \\
\hline \multirow[t]{4}{*}{ Age group } & $18-25$ & 227 & 10 & 83 & 154 & 237 \\
\hline & $26-35$ & 29 & 13 & 19 & 29 & 48 \\
\hline & $36-45$ & 6 & 5 & 3 & 11 & 14 \\
\hline & $46+$ & 1 & 6 & 5 & 3 & 8 \\
\hline Total & & 263 & 34 & 110 & 197 & $307 *$ \\
\hline
\end{tabular}

* Only 307 out of the 350 respondents completed the demographic section of the survey.

\section{Results}

The students were first asked to rank order their preferences based on their interest in participating in the three mobility activities: study tours, study exchange and overseas internship/work placements. While students were interested in all three, overseas internship/work placements garnered the most first preferences. 
Table 2: Preferred international mobility activities $\mathrm{N}=350$

\begin{tabular}{|l|l|l|l|}
\hline & Rank order & Rank order & Rank order \\
\hline Activity & \multicolumn{1}{|c|}{$\mathbf{1}$} & $\mathbf{2}$ & $\mathbf{3}$ \\
\hline Overseas internship/work placement & $45 \%$ & $26 \%$ & $29 \%$ \\
\hline Study exchange & $24 \%$ & $33 \%$ & $42 \%$ \\
\hline Study tour & $17 \%$ & $35 \%$ & $48 \%$ \\
\hline
\end{tabular}

Students were asked a series of questions regarding their preferences for relatively short-term international work placements or internships. The students were asked to assess each destination as a preferred work placement location. The majority of respondents nominated North America as their preferred location for gaining international work experience. South Asia was not a preferred choice for work placements by almost half of the respondents.

Table 3: Preferred location for work placement

\begin{tabular}{|l|c|c|}
\hline \multicolumn{2}{|c|}{} & Frequency \\
\hline \multirow{2}{*}{ North America } & YES & 304 \\
\cline { 2 - 3 } & NOT AT ALL & 3 \\
\hline \multirow{2}{*}{ UK and Ireland } & YES & 302 \\
\cline { 2 - 3 } & NOT AT ALL & 4 \\
\hline \multirow{2}{*}{ Europe and Scandinavia } & YES & 300 \\
\cline { 2 - 3 } & NOT AT ALL & 6 \\
\hline \multirow{2}{*}{ South America } & YES & 253 \\
\cline { 2 - 3 } & NOT AT ALL & 49 \\
\hline Southeast Asia & YES & 249 \\
\cline { 2 - 3 } & NOT AT ALL & 55 \\
\cline { 2 - 3 } & YOT AT ALL & 87 \\
\hline
\end{tabular}

As Table 3 shows, the students report strong preferences for English speaking countries and Europe for work placement destinations. This reflects the familiarity of Australian higher education systems with the US, UK and Europe media and communication 
systems. Interestingly, Japan is mentioned as a preferred destination by 82 per cent of the respondents. Despite Australia's proximity to Southeast Asia, China and South Asia, Australian students still preferred the Western countries for their work placement. When probed into why they chose these locations, almost half of the respondents believed that the countries in North America and the UK provided the best industry practice they can experience. This finding also supports previous reports that Australian students tend to "seek out international experience in English speaking countries such as America, Canada and the UK" (Davis et al. 1999, cited in Crossman \& Clarke, 2010; Ziguras \& McBurnie, 2011).

In addition to location, students were also asked how much they would be willing to pay for their study tour and how they would fund the study tour. These were then tabulated by location to derive the following table.

Table 4: Location of proposed tour, willingness to pay and potential funding sources

\begin{tabular}{|c|c|c|c|c|c|}
\hline & \multicolumn{4}{|c|}{ Source of Funds for Travel } \\
\hline & & SELF & FAMILY & WORK & $\begin{array}{l}\text { TRAVEL } \\
\text { GRANT }\end{array}$ \\
\hline \multirow{4}{*}{$\begin{array}{l}\text { How much willing } \\
\text { to pay for Asia }\end{array}$} & Less than $\$ 1000$ & 128 & 81 & 88 & 49 \\
\hline & 1001 to 2999 & 114 & 82 & 94 & 54 \\
\hline & 3000 to 4999 & 9 & 10 & 9 & 2 \\
\hline & More than 5000 & 0 & 0 & 0 & 0 \\
\hline \multirow{4}{*}{$\begin{array}{l}\text { How much willing } \\
\text { to pay for North } \\
\text { America }\end{array}$} & Less than $\$ 1000$ & 40 & 33 & 29 & 19 \\
\hline & 1001 to 2999 & 151 & 77 & 98 & 54 \\
\hline & 3000 to 4999 & 64 & 62 & 62 & 32 \\
\hline & More than 5000 & 1 & 2 & 2 & 1 \\
\hline \multirow{4}{*}{$\begin{array}{l}\text { How much willing } \\
\text { to pay for Europe }\end{array}$} & Less than $\$ 1000$ & 34 & 26 & 26 & 15 \\
\hline & 1001 to 2999 & 136 & 75 & 84 & 51 \\
\hline & 3000 to 4999 & 75 & 68 & 71 & 37 \\
\hline & More than 5000 & 11 & 5 & 11 & 3 \\
\hline
\end{tabular}

Table 4 indicates that students generally expect to fund their travel themselves, although they will attempt to explore other sources for additional funding. What this table also reveals is that students are willing to pay between $\$ 1000-3000$ for their travel to North America and Europe and slightly less for Asia. 
Students were asked about when they would like to time their experiences and how long they would like to have to undertake their internship. As Table 4 reveals, respondents prefer to undertake international work placements between two-three weeks with most indicating that the mid-year June-July break as an ideal time. In the Australian academic calendar, this period is the winter break between first and second semesters.

Table 5: Preferred duration and timing of international work placements

\begin{tabular}{|c|c|c|c|c|c|c|c|c|}
\hline & \multicolumn{4}{|c|}{ Preferred duration } & \multicolumn{3}{|c|}{ Preferred time period } \\
\hline & & $\begin{array}{c}\text { One } \\
\text { week }\end{array}$ & $\begin{array}{c}\text { Two } \\
\text { weeks }\end{array}$ & $\begin{array}{l}\text { Three } \\
\text { weeks }\end{array}$ & Other & $\begin{array}{l}\text { June- } \\
\text { July }\end{array}$ & $\begin{array}{l}\text { November } \\
\text { December }\end{array}$ & $\begin{array}{l}\text { January- } \\
\text { February }\end{array}$ \\
\hline & & Freq & Freq & Freq & Freq & Freq & Freq & Freq \\
\hline \multirow[t]{2}{*}{ Gender } & Male & 3 & 35 & 54 & 18 & 65 & 22 & 21 \\
\hline & Female & 2 & 62 & 103 & 30 & 120 & 36 & 41 \\
\hline \multirow{2}{*}{$\begin{array}{l}\text { Student } \\
\text { type }\end{array}$} & International & 2 & 24 & 23 & 16 & 41 & 12 & 11 \\
\hline & Local & 3 & 82 & 152 & 47 & 162 & 53 & 58 \\
\hline
\end{tabular}

Students were also asked about their reasons for travelling for work placement. In the main students agreed with the statements below. Table 6 indicates that students recognized the value of gaining international work experience and broadening their horizons in developing their careers as media and communication practitioners. While students valued work placements for making their CVs look good, the main driver for wanting to go on international internships is to broaden and enhance their learning experiences.

Table 6: Reasons for traveling abroad for work placement

\begin{tabular}{|l|l|l|l|l|l|l|}
\hline & Mean & $\begin{array}{l}\text { SA } \\
\mathbf{1}\end{array}$ & $\begin{array}{l}\mathbf{A} \\
\mathbf{2}\end{array}$ & $\begin{array}{l}\mathbf{N} \\
\mathbf{3}\end{array}$ & $\begin{array}{l}\text { D } \\
\mathbf{4}\end{array}$ & $\begin{array}{l}\text { SD } \\
\mathbf{5}\end{array}$ \\
\hline I can broaden my horizons & 1.16 & 265 & 32 & 7 & 2 & \\
\hline I can get international experience & 1.11 & 274 & 29 & 1 & 1 & \\
\hline $\begin{array}{l}\text { Everyone should do it at some } \\
\text { stage }\end{array}$ & 2.21 & 99 & 88 & 83 & 21 & 13 \\
\hline $\begin{array}{l}\text { I can meet new people and make } \\
\text { new friends }\end{array}$ & 1.57 & 166 & 105 & 28 & 2 & 2 \\
\hline $\begin{array}{l}\text { It will look really good on my } \\
\text { CV }\end{array}$ & 1.43 & 203 & 79 & 17 & 5 & 1 \\
\hline
\end{tabular}




\begin{tabular}{|l|l|l|l|l|l|l|}
\hline $\begin{array}{l}\text { I like the idea of participating in } \\
\text { different cultures }\end{array}$ & 1.44 & 206 & 71 & 21 & 6 & 1 \\
\hline $\begin{array}{l}\text { I do not want to stay in Australia } \\
\text { for my study }\end{array}$ & 2.19 & 108 & 86 & 74 & 14 & 22 \\
\hline
\end{tabular}

\section{Discussion and conclusion}

The results of the study confirm that student respondents see the value of international student mobility. Among the student mobility activities, respondents ranked international work placements over semester exchange and short term study tours. This finding indicates that students view international work experience as a valuable investment for their professional career development. However this perspective may be influenced by their own views of the global media and communication industry of which they hope to be part. Moreover, work placements seem to be the least disruptive to their academic progress unlike semester exchange where course equivalency is paramount. Furthermore, some work placements offer some financial assistance in the form of travel allowances which help alleviate students' financial concerns.

However one of the challenges revealed in the study is the students' preferred duration for their international work placements. While the students reported a preference for three weeks away, this could be problematic for host employers who may prefer longer duration. Most employers prefer a minimum of six weeks to give students sufficient time to acclimatize, orient themselves with the local culture and systems, be inducted into the organization and undertake the work. For example, the Agence France Presse in Singapore preferred interns to be with them for six months to give both students and host employer ample time for orientation and completion of work tasks (Coloma 2009, personal comm). Similarly, RMIT's International Industry Experience and Research Program (RIIERP) offers students six- to twelve-month placements in international companies around the world 
http://www.rmit.edu.au/browse;ID=lts36z94rdw61. Other international internship courses require students to undertake placement between 40-80 working days, or approximately between eight to 16 weeks (http://www.rmit.edu.au/courses/045531). Understandably, onshore internships normally require four weeks because students do not need additional time to familiarize themselves with the culture and the context in which they will undertake their work experience. The students' preference for shorter internship periods may also reflect their financial concerns especially if the placements are unpaid. While some programs such as RIIERP and international media fellowships come with some allowances, costs while overseas can still be a limiting factor.

As previously mentioned, overseas mobility activities are opportunities for students to expand their social and professional networks and international work placements are viewed to enhanced career prospects. As students have mentioned, two thirds of the respondents strongly agreed with the statement "It (international work placement) will look really good on my CV" and almost 90 percent strongly agreed that it will "broaden their horizons". This finding supports previous studies (Loyland \& Ellingson, 2009) that suggest a relationship between networking and international internships.

Students' preference for international internships slightly ahead of semester exchanges and study tours also indicate their understanding of the competitive labour market and the needs of potential employers. As Crossman and Clarke's (2010) study noted, employers reported that international work experience was a critical factor in recruitment and promotion processes.

This study's further support of previous studies that Australian students prefer English-speaking countries as their destination of choice however provides some interesting dilemmas. Perhaps as the students indicated, the choice of English-speaking 
countries as preferred work placement destinations has more to do with best practice particularly in media and communication industries. For the students who had an idea of where they want to go, they mentioned media organisations (British Broadcasting Corporation, New York Times, Reuters), advertising agencies (Young \& Rubicam, Saatchi \& Saatchi), museums (Museum of Modern Art, Victoria and Albert Museum), games and animation companies (Pixar, Disney, EA Games) and public relations consultancies (Edelman PR).

While Crossman and Clarke's (2010) study reported how employers regarded Asian languages as an advantage particularly within the context of increasing trade in Southeast Asia, China and Japan, the students do not seem to see language training as a priority. Because the students expressed interest in English-speaking countries, it is no surprise that language and cultural training ranked third in their priorities for preparation for overseas work placements. Practical preparations such as saving money and travel documentations were deemed more important. However it is also possible that students do not see the need for language training because globalisation has also "accelerated the need for a common language and English has become the lingua franca of the world" (Chan \& Dimmock, 2008:194).

If Australian students do not actively pursue international activities in the Asia Pacific region, what competitive advantage can they offer, especially over American, Canadian or British students? Australian students must take advantage of their proximity to Asia and soon realize that the economic powers are shifting eastward. Furthermore, if the Australian government wishes to engage with the Asia-Pacific region more strategically, more funding grants and scholarships must be provided toward student mobility programs. Funding programs such as the University Mobility in Asia and the Pacific (UMAP) and Endeavour Awards have offered scholarships to 
Australian students to undertake mobility activities to Asia need to be continued and sustained for the long term.

Undoubtedly, international work placements extend students' understanding of global practices offer experiential learning in different cultural contexts. This valuable experience can lead to more nuanced knowledge of political, economic and cultural information which can lead to media and communication students' role as cultural interpreters. Within the mediated world in which we live, culturally sensitive and internationally savvy media practitioners can make the difference for a peaceable world.

\section{References}

Altbach, P. G., Reisberg, L., \& Rumbley, L. E. (2010). Tracking a global academic revolution. Change: The Magazine of Higher Learning, 42(2), 30-39.

Baldauf Jr, R. B., \& White, P. (2011). Participation and collaboration in tertiary language education in Australia.

Barron, P., Baum, T., \& Conway, F. (2007). Learning, Living and Working: Experiences of international postgraduate students at a Scottish University. Journal of Hospitality and Tourism Management, 14(2), 85-101.

Baruch, Y., Budhwar, P. S., \& Khatri, N. (2007). Brain drain: Inclination to stay abroad after studies. Journal of World Business, 42, 99-112.

Biddle, N. (2006). The labour market status of Australian students: Who is unemployed, who is working and for how many hours? Unpublished Masters, Monash University, Clayton.

Bourke, A. (2000). A model of the determinants of international trade in higher education. Service Industries Journal, 20(1), 110-138. 
Chan W.W.Y. \& Dimmock, C. (2008). The internationalization of universities: Globalist, internationalist and translocalist models. Journal of Research in International Education, 7(2), 184-204.

Chase, M. M. (2010). Student Transfer Policies and Practices in the United States and Europe: Mobility without Loss of Credit. Journal of Student Affairs Research and Practice, 47(1), 99-119.

Clifford, V. A. (2011). Internationalising the home student. Higher Education Research \& Development, 30(5), 555-557.

Coates, H., \& Edwards, D. (2011). The Graduate Pathways Survey: New Insights on Education and Employment Outcomes Five Years after Bachelor Degree Completion. Higher Education Quarterly.

Coleman, J. A. (2006). English-medium teaching in European Higher Education. Language teaching, 39, 1-14.

Crossman, J. E. \& Clarke, M. (2010). International experience and graduate employability: stakeholder perceptions on the connection. Higher Education 59, 599-613.

Czinkota, M. R. (2005). Loosening the shackles: The future of global higher education. Paper presented at the World Trade Organization, Symposium on cross-border supply of services.

Daly, A. (2011). Determinants of participating in Australian university student exchange programs. Journal of Research in International Education, 10(1), 58.

De Ville, P., Martou, F., \& Vandenberghe, V. (1996). Cost benefit analysis and regulatory issues of student mobility in the EU. European Journal of Education, 31(2), 205-222. 
Doyle, S., Gendall, P., Meyer, L. H., Hoek, J., Tait, C., McKenzie, L., et al. (2010). An investigation of factors associated with student participation in study abroad. Journal of studies in International Education, 14(5), 471.

Findlay, A. M., King, R., Smith, F. M., Geddes, A., \& Skeldon, R. (2011). World class? An investigation of globalisation, difference and international student mobility. Transactions of the Institute of British Geographers.

Gleeson, J. (2011). The European Credit Transfer System and curriculum design: product before process?

Goodman, B., Jones, R., \& Macias, M. S. (2007). An exploratory survey of Spanish and English nursing students' views on studying or working abroad. Nurse Education Today, In press.

Gothard, J., \& Butcher, L. (2010). Bringing the learning home: re-entry programs to enhance study abroad outcomes in Australian universities. Perth: Murdoch University.

Hemsley-Brown, J., \& Goonawardana, S. (2007). Brand harmonization in the international higher education market. Journal of Business Research, 60(9), 942948.

Johnstone, D. B. (2010). 12. American higher education in an increasingly globalized world: the way ahead. Higher Education in a Global Society, 200.

Kehm, B. M. (2005). The Contribution of International Student Mobility to Human Development and Global Understanding. US-China Review, 2(1 (Serial 2) January), 18-24.

Kelo, M., Teichler, U., \& Wachter, B. (2006). Toward improved data on student mobility in Europe: Findings and concepts of the Eurodata study. Journal of Studies in International Education, 10(3 Fall), 194-223. 
Kemp, N. (2011). Higher Education and International Student Mobility in the Global Knowledge Economy. By K. Guruz. British Journal of Educational Studies, 59(3), 355-357.

King, R., Findlay, A., \& Ahrens, J. (2010). International student mobility literature review. Higher Education Funding Council for England, Bristol.

Larsen, K., Martin, J. P., \& Morris, R. (2002). Trade in Educational Services: Trends and Emerging Issues. The World Economy, 25(6), 849-868.

Larsen, K., Momii, K., \& Vincent-Lancrin, S. (2004). Cross-border higher education: an analysis of current trends, policy strategies and future scenarios. London: The Observatory on borderless higher education.

Li, M., \& Bray, M. (2007). Cross-border flows of students for higher education: Pushpull factors and motivations of mainland Chinese students in Hong Kong and Macau. Higher Education, 53(6), 791-818.

Li, M., \& Zhang, Y. (2011). Two-Way Flows of Higher Education Students in Mainland China in a Global Market: Trends, Characteristics and Problems. Higher Education in the Asia-Pacific, 309-327.

Loyland, M. \& Ellingson, D. (2009). Using networks to access international internship opportunities. International Journal of Networking and Virtual Organisations, 6 (4), 356-366.

Marcotte, C., Desroches, J., \& Poupart, I. (2007). Preparing internationally minded business graduates: the role of international mobility programs. International Journal of Intercultural Relations, 31, 655-668.

Marginson, S., \& van der Wende, M. (2007). Globalisation and higher education. Paris, France: OECD Directorate for Education. 
Metcalf, H. (2003). Increasing Inequality in Higher Education: The role of term-time working. Oxford Review of Education, 29(3), 315-329.

Mourad, M., Ennew, C., \& Kortam, W. (2011). Brand equity in higher education. Marketing Intelligence \& Planning, 29(4), 403-420.

Mutlu, S., Alacahan, O., \& Erdil, M. (2010). Comparison of the personal and cultural change taking place between EU Erasmus students and Turkish Erasmus students (within the sample of Adam Mickiewicz University in city of Poznan, Poland). Eurasian Journal of Anthropology, 1(1), 33-43.

Naidoo, V. (2006). International education: A tertiary-level industry update. Journal of Research in International Education, 5(3), 323-345.

Scott, K. (2011). Issue 25-JUN 16. Europe, 16(25).

Strehl, F., Reisinger, S., \& Kalatschan, M. (2007). Funding systems and their effects on higher education systems - International report (Education Working Paper). Paris, France: OECD Directorate for Education.

Teichler, U. (2010). Internationalising Higher Education: Debates and Changes in Europe. Changing Educational Landscapes, 263-283.

Teichler, U., \& Janson, K. (2007). The professional value of temporary study in another European Country: Employment and work of former ERASMUS students. Journal of Studies in International Education, 11(3/4 Fall/ Winter), 486-495.

Throsby, D. (1998). FINANCING AND EFFECTS OF INTERNATIONALISATION IN HIGHER EDUCATION: The Economic Costs and Benefits of International Student Flows: OECD Centre for Educational Research and Innovation.

Tremblay, K. (2005). Academic mobility and immigration. Journal of Studies in International Education, 9(3 Fall), 196-228. 
Van Den Broek, S., Muller, B., Dekker, N., Bootsma, A., \& Cate, O. T. (2010). Effect of the new Bologna bachelor degree on career considerations of medical students in one medical school. Medical Teacher, 32(12), 997-1001.

Waters, J. L. (2006). Geographies of cultural capital: education, international migration and family strategies between Hong Kong and Canada. Transactions of the Institute of British Geographers, 31(2), 179-192.

Ziguras, C., \& McBurnie, G. (2011). International Student Mobility in the Asia-Pacific: From Globalization to Regional Integration? Higher Education in the AsiaPacific, 123-140. 